\title{
RELIGIONSSOCIOLOGIEN I EN KULTUR I STADIG FORANDRING
}

\author{
Lars Ahlin
}

\begin{abstract}
ENGLISH ABSTRACT: A first precondition for a proper understanding of the religious landscape of today is, when we construct our surveys, that the dominating traditional religion is not used as point of reference. Secondly we as sociologists of religion must take into account the theories of contemporary sociologists concerning the individual's situation in late modern society. The last point is; if we want sociologically founded understanding of the changes of the religious field, we must take into account theories of the kind, represented by Mary Douglas' grid/group-model, that connect the social experiences of the individual with his/her type of religiosity.
\end{abstract}

DANSK RESUME: Muligheden for at konstruere det religiøse felt i dag og dets forandringer på en adcekvat og sociologisk relevant måde forudscetter, at en dominerende, traditionel religion ikke fungerer som referencepunkt. En relevant forståelse af individets situation i det senmoderne samfund forudscetter inddragelse af indsigter fra almen sociologi. Hvis vi skal forstå det religiøse felts forandring på en sociologisk relevant måde, skal vi desuden som udgangspunkt have en teori, der sammentcenker enkeltindividers sociale erfaringer og typer af religiøsitet.

KEYWORDS: Sociology of religion, Surveys, Late modernity

I lighed med andre videnskabelige discipliner kan religionssociologi betyde mange forskellige ting, og de enkelte religionssociologiske forskere kan anlægge meget forskellige perspektiver på deres forskningsfelt. Som en sociolog, der beskæftiger sig med religion, ser jeg det som min opgave at afdække forandringer inden for det religiøse felt. Min ambition er ikke begrænset til dette; men mit primære formål er at forstå de samfundsmæssige processer, der forårsager de religiøse forandringer. Et nødvendigt udgangspunkt, men kun et udgangspunkt, for mit arbejde er derfor at konstruere eller rekonstruere både det nuværende religiøse felt og det, som fungerer som mit sammenligningspunkt.

Med begrebet 'kultur' forstår jeg et samfund i dets helhed som eksempelvis det danske, der i sig kan siges at indeholde flere forskellige, religiøse kulturer. Her kan man tale om en indremissionsk kultur, en grundtvigiansk, en liberalt kristen, en sunnimuslimsk, en shiamuslimsk og mange mange andre religiøse kulturer. Hvert enkelt af disse kan naturligvis og uproblematisk analyseres religionssociologisk; men dette er 
ikke mit primære anliggende. Inden for hver af de religiøse kulturer findes der enkelte mennesker med bestemte religiøse holdninger. Endnu flere mennesker findes udenfor, med eller uden religiøse holdninger. Det, som jeg benævner det 'religiøse felt', er alle disse mennesker, både de som har mere eller mindre tydelige trosforestillinger, de som har haft sådanne, og de som kan tænkes at få sådanne. Alle disse mennesker, dvs. alle mennesker i Danmark, er på forskellige måde genstand for samfundsmæssige processer, der påvirker dem også i religiøs henseende. Min interesse er at afdække, hvilke individer der påvirkes af hvilke samfundsforandringer og hvorfor, samt hvordan deres relation til det religiøse dermed forandres.

\section{Nødvendigheden af store kvantitative undersøgelser}

Når jeg taler om at konstruere denne kultur eller det religiøse felt i Danmark, har jeg ikke, på trods af et meget omfattende og informationsrigt, empirisk materiale til hensigt at konstruere den totale kultur eller det religiøse felt i dets helhed, men kun bestemte og begrænsede aspekter deraf. Udvælgelsen af disse aspekter er primært bestemt af den teori, jeg arbejder ud fra, og sekundært bestemt af muligheden for at tilvejebringe fyldestgørende empiri.

I forhold til at konstruere det religiøse felt som helhed er visse metoder efter min mening definitivt mere velegnede end andre. Jeg mener, at store spørgeskemaundersøgelser over et tilfældigt udvalg af befolkningen her er den eneste mulige fremgangsmåde. Kvalitative metoder har dog forcer, som ikke skal undervurderes. Dels er både feltstudier og kvalitative interviews de bedste ved undersøgelser af eksempelvis små afgrænsede religiøse samfund. Dels har interviews en meget stor værdi i forberedelsesfasen for en kvantitativ undersøgelse. Gennem kvalitative dybdeinterviews er det nemlig muligt at få øje på trosforestillinger og religiøse praksisformer, hvis tilstedeværelse forskeren måske ikke tidligere været bevidst om. Dette giver mulighed at gøre spørgsmålene mere relevante, samtidig med at de præsenterede svaralternativer bliver mere nuancerede og dækkende. Men igen, hvis formålet er at konstruere et religiøst felt, er de kvantitative spørgeskemaundersøgelser det eneste virkeligt brugbare værktøj. Denne type af undersøgelser har naturligvis ikke de samme muligheder for at gå i dybden som fx kvalitative dybdeinterviews med hensyn til eksempelvis spørgsmålet om, hvorvidt enkelte individer har internt konsistente trosforestillinger eller ej. Gennem et interview kan man få en detaljeret beskrivelse af de trosforestillinger, den enkelte har, og derfor også mulighed for at konfrontere den interviewede med eventuelle 'modsigelser' ${ }^{\text {' }} \mathrm{i}$ disse og undersøge, hvordan respondenten forklarer dette. Endvidere er det $i$ en interviewsituation muligt at få ekspliciteret, i hvilke situationer de forskellige trosforestillinger bliver aktualiseret. Jo mere viden vi har fået gennem dybdeinterviews eller tidligere undersøgelser, jo nemmere et det derfor at formulere spørgsmål til et spørgeskema, der kan påvise eventuelle

\footnotetext{
${ }^{1}$ Ordet 'modsigelse' sættes i anførselstegn, eftersom det drejer sig om udsagn, som den pågældende forsker med dennes perspektiv og med dennes bestemte referencerammer opfatter som modsigende. Med stor sandsynlighed vil den enkelte interviewperson ikke opfatte de samme udsagn som selvmodsigende.
} 


\section{Religionssociologien i en kultur i stadig forandring}

'modsigelser' og hvordan forskellige 'modsigelsesfulde' trosforestillinger kan være kombineret. Endvidere er det gennem spørgeskemaer muligt at opdage 'mønstre' i befolkningen, da skemaerne henvender sig til et repræsentativt udvalg af hele befolkningen. Med mønster mener jeg, at bestemte kombinationer er knyttet mere til visse baggrundsvariabler end til andre. De aktuelle baggrundsvariabler kan enten være demografiske eller variabler, der har sin grund i samfundsmæssige forhold på andre måder. Dette giver da mulighed for at konstatere, om der er sammenhæng mellem religiøse positioner og andre samfundsmæssige forhold.

\section{Tidligere gennemførte spørgeskemaundersøgelser}

Hvad kan man så sige om de hidtidige undersøgelser? Har de givet et retvisende billede af det religiøse felt og det, som ligger bag eventuelle forandringer? Det er højst tvivlsomt, om det er muligt at svare ja til dette, da de hidtidige undersøgelser generelt kan siges have haft et mere begrænset formål, nemlig at afdække afstanden mellem på den ene side forskellige befolkningsgrupper i termer af demografiske variabler som køn, alder og uddannelse, og på den anden side den dominerende (eller det som er blevet opfattet som den dominerende) religiøse institution, og hvordan denne afstand er blevet forandret over tid. Dette er sandt både i forhold til de store, nu verdensomfattende, værdiundersøgelser og fx den europæiske RAMP-undersøgelse ${ }^{2}$.

Hvorfor har de nævnte undersøgelser og mange andre da haft den beskrevne fokusering? Der er flere forskellige grunde, der samtidig er tæt sammenknyttede. En forklaring er, at det er meget nemmere at sætte ord på og formulere spørgsmål/svaralternativer til det, vi kender godt, og som står tydeligere frem end det, som er diffust, og som vi måske kun fornemmer. En anden forklaring er, at denne type religionssociologi har været forholdsvis tæt knyttet til den etablerede kirke eller i det mindste et teologisk fakultet. Yderligere en forklaring kan være, at mange religionssociologer som enkeltpersoner har haft tætte bånd til den etablerede og dominerende trosretning. De to sidste forklaringer kan have haft til resultat at konstruktionen af undersøgelserne, bevidst eller ej, blev lavet på en sådan måde, at den dominerende trosretnings interesser blev tilgodeset.

\section{Et nødvendigt første trin}

Et første trin på vejen mod spørgeskemaer, der kan give mere retvisende billeder af den religiøse situation, er derfor at komme væk fra brugen af den etablerede og dominerende religion som det naturlige referencepunkt. Dette er på sin side en nødvendig forudsætning, hvis man skal få mulighed for at konstruere spørgeskemaer, der muliggør sociologisk begrundede analyser af, hvad der ligger bagved den forandring, der er sket i det religiøse felt.

Tilsvarende problem påpegede Bryan Wilson allerede 1973 i sin bog Magic and Milleneum, hvor han diskuterede, hvordan forskellige religiøse bevægelser (sekter)

\footnotetext{
${ }^{2}$ Religious And Moral Pluralism (en spørgeskemaundersøgelse der brugte sammenlignelige spørgsmål i 11 europæiske lande).
} 
burde klassificeres. Tidligere, mente Wilson, havde udgangspunktet været den weberianske dikotomien kirke-sekt, hvilket ikke længere var rimeligt. Hvis en klassifikation af sekter skulle laves på en sociologisk forsvarlig måde, var man ifølge ham nødt til at holde sig væk fra sammenligninger med den kristne kirke, og hvordan og i hvilken grad de enkelte sekter var afvigelser derfra. Han peger på, at det, der er karakteristisk for den kristne kirke, som fx en sammenhængende doktrin og en formel organisation, ikke på nogen måde har været af samme betydning for religiøse retninger uden for Europa.

Den samme type indvending kan gøres i dag, hvor meget af inspirationen for den nye religiøsitet kommer fra østerlandske religioner eller fra sekulære psykologier som den humanistiske. I dag er det meget tydeligt et spørgsmål om eklektiske og synkretistiske holdninger, som ikke nødvendigvis danner en sammenhængende helhed, men tværtimod ofte fremviser modsatte kendetegn.

I stedet for formelle organisationer er den nye religiøsitet i dag organiseret $i$ flydende størrelser som netværk eller løse organisationer med ikke-absolutte grænser eller slet ikke organiseret, men et helt individuelt anliggende. Vi er således nødt til at komme væk fra den institutionaliserede religion som referencepunkt, som model for hvordan en 'rigtig' religion ser ud. Dette betyder naturligvis ikke, at denne skal ekskluderes fra vore undersøgelser, men at den institutionaliserede religion skal studeres med samme 'briller' som andre religiøse udtryk.

\section{Næste trin}

Hvad er det da, der er blevet overset på grund af den ovenfor beskrevne fokusering på den etablerede kirke? I meget generelle termer er det, at vores kultur, samfundet, de sociale forhold, ikke er noget statisk, men noget der er under en stadig hurtigere forandring, og at de religiøse udtryk, det religiøse felt, som følge af dette, også er under stadig forandring.

Dette har mange empirikere inden for religionssociologien dog tilsyneladende overset, hvilket er bemærkelsesværdigt, da den stadige forandring har været i fokus hos højt estimerede teoretiker i adskillige år, både inden for den generelle sociologi og inden for religionssociologien. Mange forskere i dag, både generelle sociologer og religionssociologer, er enige $i$, at der generelt er sket en aftraditionalisering, hvilket også implicerer en religiøs aftraditionalisering. Ydermere er denne aftraditionalisering en forudsætning for, at religionen i øget grad er blevet en forbrugervare på linie med andre varer, og at religionen er noget, der i dag bruges med det formål at konstruere ens selvidentitet og ens egen biografi. Disse udviklinger er man nødt at have for øjne, hvis man på en rimelig måde skal have mulighed at give et retvisende billede af, hvordan det religiøse landskab faktisk ser ud i dag, og hvorfor det ser sådan ud.

I Religion in Modern Times (2000) skelner Heelas og Woodhead mellem fem varianter af aftraditionalisering, der har direkte relevans for religionens situation: 


\section{Religionssociologien i en kultur i stadig forandring}

Traditionens svaekkelse, dvs. at moderne, kritisk fornuft har undermineret traditionelle tros- og praksisformer.

Selvets sakralisering, hvilket har sin grund i kulturens generelle 'turn to the self'.

Religionens individualisering, hvilket er resultat af den udvikling i den moderne verden, der kan betegnes 'culture of choice' som en følge af forbrugerkulturens udvikling.

Instrumentalisering og kommercialisering af religion, hvilket både har sin grund i "the turn to the self" og udviklingen af forbrugerkulturen.

Universaliseringen af religion. Dette handler om, at man i dag tager afstand fra traditioner, der understreger forskellen mellem forskellige religioner. I stedet for pointeres den fælles kilde for alle religioner (s. 344).

Aftraditionaliseringen og dens betydning for religionen er naturligvis ikke nogen nyhed for sociologer med specielt fokus på religion, men noget, mange har været bevidste om under lang tid. I denne sammenhæng tænker jeg ikke mindst på Thomas Luckmann, der for 40 år siden i Invisible Religion (1967) diskuterede dette. Flere af de udtryk for aftraditionalisering, som Woodhead og Heelas præsenterer, kommer nemlig op til diskussion i denne bog. Luckmann er inde at berøre forbrugerismens betydning, men også at den moderne identitetskonstruktion og biografikonstruktion har fået en betydning for religiøsiteten.

Foruden at være 'subjektiv og privat' er den moderne religion, den usynlige religion, ifølge Luckmann, til forskel fra den traditionelle ikke en sammenhængende størrelse. Den moderne 'autonome' forbruger vælger fra det tilgængelige udbud af meningskomponenter og bygger et fleksibelt, men ømtåligt private trossystem. Ømtåligt dels da det ikke har nogen grund i en fast plausibilitetsstruktur, dels da det ikke har nogen fast indre konsistens (Luckmann 1967, 102).

Samme ræsonnementer fører han videre i artikler i 1990 og 1999. I artiklen fra 1999 siger Luckmann endvidere, at meget af det, som tiltrækker nutidens mennesker, finder man i det, som bliver benævnt "new age", hvilket er et meget synkretistisk miljø, hvor individet for sit vedkommende gør sit eget synkretistiske valg. Og den store forskel i forhold til traditionel religion er at " $(t)$ here is no canonized dogma, no personal recruitment system, no disciplinary apparatus" (Luckmann 1999, 255).

Luckmann er ikke hellere den eneste religionssociolog, der tidligt diskuterede temaer, der berører aftraditionaliseringen. Her kan nævnes Roberth Wuthnow og hans bog The Consciousness Reformation (1976) og Robert Bellah med Habits of the Heart (1985). I den sidstnævnte fortæller Bellah om en kvinde, som kalder sin tro Sheilaisme efter sit eget navn. Sheilaismen, en helt individuel religion, har ifølge Bellah sin grund i individets forsøg på at komme væk fra ydre autoriteter og i stedet som basis for troen have en personlig religiøs erfaring. Det samme kommer han tilbage til bl.a. i Beyond Belief (1991). Her siger han, at et aspekt af den store moderne forandring er autoritetens internalisering, hvilket har haft en afgørende betydning for religionen. I dag, siger han, 
er mennesker intenst optagne af autentiske personlige oplevelser og erfaringer, og alt, der kommer fra autoriteter, betragtes som suspekt.

Et andet aspekt af den senmoderne tid, med grund i aftraditionaliseringen, er den tiltagende forbrugerisme, hvilket, som nævnt tidligere, har forandret religiøsiteten og den måde, man i dag forholder sig til religion på. Forbrugerisme er noget, som sociologen Zygmunt Bauman (1999) giver en helt særlig vægt, idet han skelner vores nuværende 'forbrugersamfund' fra det tidligere 'produktionssamfund'. Tidligere "engagerede samfundet sine medlemmer primcert som producenter... I sit senmoderne eller postmoderne stadium engagerer samfundet sine medlemmer - en gang mere primcert - $\mathrm{i}$ deres egenskab af forbrugere" (Bauman 1999, 40) ${ }^{3}$. Dette skal dog ikke forstås således, at der har været et totalt skifte mellem de to samfundstyper, men at der er sket en forskydning, der "er af meget stor betydning for i det store hele hvert enkelt aspekt af samfundet, kulturen og individets liv" (Bauman 1999, 40). En del af dette er også, at identiteter, i lighed med forbrugervarer, er noget man køber for at forbruge. Hvad man tilsyneladende har brug for i mødet med livsudfordringerne i dag, synes ifølge Bauman at være identiteter, der er løst sammensatte af komponenter, der ikke er alt for varige, er nemme at tage af og er nemt udskiftelige (Bauman 1999, 47).

Hvis dette er en rigtig vurdering, har det naturligvis en stor betydning også for religiøsiteten. Det er også helt tydeligt, at forbrugerattituden også er udbredt inden for det religiøse område. Eksempelvis kommer Reginald Bibby tilbage til dette flere gange, når han beskriver situationen i Canada. Han siger således i Fragmented Gods (1987), at religionen er blevet en nydeligt indpakket forbrugerartikel, som kan købes eller kasseres i forhold til det enkelte menneskes egne forbrugernykker. Og canadierne har ikke brug for sammenhængende trossystemer, men benytter sig selektivt af trosforestillinger og praktiker, selv om de stadig identificerer sig med en traditionel tradition. I Unknown Gods (1993) siger Bibby noget, der kan være en del af forklaringen på den empiriske religionssociologis begrænsede udsyn: Når forskere insisterer på, at mennesker har brug for sammenhængende trossystemer, fortæller det mere om, hvordan de selv fungerer, end om "how the world works"(Bibbly 1993, 116).

En anden forfatter, der diskuterer forbrugerismens betydning for religion og den enkeltes religiøsitet, er David Lyon i bogen Jesus in Disneyland (2000). Han siger blandt andet, at de, der befinder sig på det religiøse marked som forbrugere, synes at konstruere deres religiøse identiteter på en dynamisk, stadig foranderlig måde. En effekt af dette er, at vi som forskere forventer os kontradiktioner i tro og praktik. Men, siger han, sociologien burde fokusere mere på, hvordan mennesker 'make a life', det vil sige på hvordan de faktisk konstruerer deres liv, end på i hvilken grad de 'make sense', det vil sige, i hvilken grad deres trossystemer er sammenhængende (Lyon 2000, 51f).

Et udtryk for forbrugerattituden og en følge af denne, nemlig tendensen til, at det moderne menneske ikke nødvendigvis har sammenhængende internt konsistente trossy-

\footnotetext{
${ }^{3}$ Min oversættelse til dansk

${ }^{4}$ Min oversættelse til dansk
} 


\section{Religionssociologien i en kultur i stadig forandring}

stemer, får man et konkret eksempel på, når man kigger på, hvordan troen på paranormale fænomener og andre ikke-traditionelle trosforestillinger uden problemer kombineres med traditionelle trosforestillinger. Det kan endvidere fungere som et eksempel på at, til trods for at det enkelte individs trosforestillinger tilsyneladende ikke 'make sense', fungerer de alligevel for den enkelte. ${ }^{5}$

Der findes således mange mennesker i vores verden, der er synkretistiske og eklektiske i deres konstruktion af verdensanskuelse, og som heller ikke har behov for, at denne skal være internt konsistent. Denne kendsgerning kan fortolkes, som at individet i dag frit kombinerer troskomponenter, 'købt' af meget forskellige udbydere, med det formål at konstruere det selvbillede, man har et behov for at holde frem for sig selv eller andre, det vil sige sin selvidentitet.

Hvorledes det moderne individ skaber og opretholder sin selv-identitet, er noget, der i høj grad beskæftiger Giddens, ikke mindst i Modernity and Self-Identity (1991). Udgangspunktet for ham er, at individet gennem aftraditionaliseringen er blevet overladt til sig selv, og spørgsmålet, det moderne menneske står overfor, er derfor: Hvem er jeg? Noget selvfølgeligt svar på dette spørgsmål findes ikke; men det er individet og kun individet selv, der skal skabe sin identitet. Et individs selvidentitet har sin grund, siger Giddens, i evnen at holde liv i en specifik fortælling om sig selv. Denne biografi er dog ikke nogen stabil basis, men skrøbelig, da individet i sin refleksivitet kunne have valgt en anden biografi, der ville have givet en anden fortælling om den udvikling frem til det, som han eller hun er i dag. Vi skaber således alle vores egen selvidentitet, og i denne kan også 'religiøse' komponenter spille en rolle. Men hvilke religiøse komponenter man vælger, hvis man overhovedet vælger nogle, kan være meget forskellige fra individ til individ. Valget er afhængigt af, hvilken selvidentitet man ønsker at præsentere for sig selv og for de omgivelser, man ser som betydningsfulde. Dette betyder da, at individets socioøkonomiske omstændigheder og dermed dets sociale erfaringer har en betydning for den selvidentitet, han eller hun konstruerer.

Zygmunt Bauman synes stort set enig med Giddens med hensyn til identitet og identitetsdannelse. Han peger i Postmodernity and its Discontents (1997) på, at det er identitetens fremvækst, der har haft størst betydning for moderniteten (s. 178). Der er dog ifølge ham en klar forskel mellem identitetsskabelsen i moderniteten og i postmoderniteten. Hvis identitetsproblemet i moderniteten var, hvordan man skulle skabe en identitet og derefter bibeholde den solid og stabil, bliver identitetsproblemet i postmoderniteten "(to) avoid fixation and keep the options open" (Bauman 1995, 81).

\section{Et sidste trin?}

Der findes som vist mængder af undersøgelser, der indikerer, at den sociale situation og dermed også den religiøse situation i efterkrigstiden er radikalt forandret og tilsyneladende forandres stadigt hurtigere. Det er en forandring, der karakteriseres af en aftradtionalisering, hvilket i høj grad understreger, at det ikke bør være den traditionelle,

${ }^{5}$ Se fx Goode 2000; Orenstein 2002; Rice 2003; Ahlin 2005. 
etablerede religion, der skal være referencepunktet, men at denne kun skal være en del af studieobjektet. Disse forandringer er noget, man i høj grad bør tage højde for i konstruktionen af spørgeskemaer, hvis man har til formål at give rimelige forklaringer på det, som er sket og som sker på det religiøse felt.

Men heller ikke dette er tilstrækkeligt ud fra et sociologisk perspektiv. Vi er nødt til at prøve på at finde sociale forklaringer på, hvorfor nogle mennesker eksempelvis har behov for at konstruere en selvidentitet, en selvfortælling, der indbefatter troen på paranormale fænomener, mens det $i$ andres selvfortælling er en vigtig del at forkaste den samme type af tro. Hvad er det, som gør, at visse individer vælger en type af religiøsitet, mens andre vælger noget helt andet? Hvilke sociologiske forklaringer kan man finde på dette?

Jeg mener, at Mary Douglas' grid/group-model i denne sammenhæng er en mulighed. Det samme mener, ikke helt overraskende, Douglas selv. Hun giver allerede i en artikel i Daedalus 1982 udtryk for en forhåbning, nemlig at "when religious sociology modernizes, it will ... develop some systematic methods of asking how different moral principles become acceptable and different versions of reality plausible" (s. 18). Der skete tilsyneladende ikke de store forandringer i denne henseende inden for religionssociologien i løbet af de følgende 20 år. I introduktionen til 1996-udgaven af Natural Symbols skriver hun nemlig, at det er muligt for religionssociologen på ny at få en stor rolle inden for sociologien. Forudsætningen for, at dette skal blive virkelighed, er dog, at religionssociologer begynder at arbejde med hendes grid/group-model eller en tilsvarende teoritype, der gør det muligt at påvise sammenhænge mellem den sociale virkelighed, mennesket lever i, og den verdensanskuelse, der synes rimelig for det (s. xxvii).

\section{Konklusion}

Min opfattelse er netop, at vi er nødt til at prøve Mary Douglas' grid/group-model eller noget tilsvarende, hvis vi skal have nogen rimelig mulighed for at forklare, hvad der ligger bagved det religiøse felts forandring. Og, gentager jeg, opgaven som religionssociolog er ikke kun er at beskrive, at konstruere et religiøst felt, men også ud fra sociologisk relevante kriterier at give en forklaring på den forandring der stadig sker inden for dette. Med det formål at gøre dette findes der naturligvis behov for at konstruere det religiøse felt, der er på spil, men også i denne konstruktion at gå meget dybere i forhold til både den faktiske religiøse virkelighed, vi lever i, end det indtil nu har været tilfældet. Og som sagt betyder dette, at religionssociologien ikke skal være bundet op til den dominerende religiøse tradition, men give det religiøse felt $i$ dets helhed en beskrivelse på dets egne betingelser. Desuden er det nødvendigt at gå sociologisk dybere end primært at operere med forholdsvis overfladiske, demografiske variabler, dvs. operere med sociologisk relevante variabler, med hvilke vi får mulighed at give en forklaring på den forandring, der sker. 


\section{Litteratur}

AHLIN, LARS

2005 Pilgrim, turist eller flykting, Symposion, Stockholm/Stehag.

BAUMANN, ZYGMUNT

1997 Postmodernity and its Discontents, Polity Press, Cambridge.

1997 Arbete, konsumtion och den nya fattigdomen, Daidalos, Göteborg.

BELLAH, ROBERTO

1985 Habits of the Heart, University of California Press, Berkeley.

1991 Beyond Belief: essays on religion in a post-traditional world, University of California Press, Berkeley.

BIBBY, REGINALDO

1983 "Searching for invisible thread: Meaning systems in contemporary Canada", Journal for the Scientific Study of Religion, 22 (2; 2).

1987 Fragmented Gods: the poverty and potential of religion in Canada, Stoddart Publ, Toronto.

1993 Unknown Gods: the ongoing story of religion in Canada, Stoddart Publ, Toronto.

DOUGLAS, MARY

1978 "The Effects of Modernization on Religious Change", Daedalus (Winter), 1-19.

1996 Natural symbols: explorations in cosmology, Routledge, London, New York.

GIDDENS, ANTHONY

1991 Modernity and Self-Identity: self and society in the late modern age, Polity Press, Cambridge.

GOODE, ERICH

2000 "Two paranormalism or two and a half? An empirical exploration" i Skeptical Inquirer 24 (1): 24-35.

LUCKMANN, THOMAS

1967 The invisible religion: The problem of religion in modern society, Macmillan, New York.

1999 "The religious situation in Europe: The background to contemporary conversions", Social Compass, 46(3): 252-258.

LYON, DAVID

2000 Jesus in Disneyland: religion in postmodern times, Blackwell Publishers, Cambridge.

ORENSTEIN, ALAN

2002 "Religion and Paranormal Belief", Journal for the Scientific Study of Religion 41(2): 301-311.

RiCE, TOM

2003 "Believe It Or Not: Religious and Other Paranormal Beliefs in the United States", Journal for the Scientific Study of Religion 42 (1): 95-106.

WILSON, BRYAN

1973 Magic and Millennium: A sociological study of religious movements of protest among tribal and third-world peoples, Heinemann, London.

WOODHEAD, Linda \& HEELAS, PAUL

2003 Religion in modern times. An interpretive anthology, Blackwell, Malden, Mass.

WUTHNOW, ROBERT

1996 The Consciousness Reformation, Univ. of California Press, Berkeley. 
Lars Ahlin

Lektor, ph.d.

Afdeling for Religionsvidenskab

Aarhus Universitet 